\title{
PERANCANGAN ARSITEKTUR KNOWLEDGE MANAGEMENT SYSTEM (KMS) PADA LEMBAGA LPPM (STUDI KASUS : LPPM STMIK STIKOM INDONESIA)
}

\author{
I Ketut Widhi Adnyana, Yuki Hidayat Wirawan \\ STMIK STIKOM Indonesia \\ e-mail : ketut.widhi@stiki-indonesia.ac.id
}

\begin{abstract}
LPPM is an institution at the university, it can be said that LPPM is a knowledge mine for academic community research activities. The function of LPPM continues to grow not only as a place to publish research works, but also as a place for knowledge to be explored. Non-print sources such as electronic journals and information that can be accessed through web media. The need for this information requires information technology support that can help LPPM place various knowledge references for researchers, lecturers, students, and others to gain quality knowledge by accessing research journals managed by LPPM. With the presence of KMS, it can certainly help in gathering, identifying potential knowledge, and managing overall knowledge. and can be used to speed up decision making on problems that have been experienced before. by using the 10 steps tiwana amrit framework. the results of this study will produce an architectural blueprint design which can later be used as a reference for the implementation of program development or subsequent development.
\end{abstract}

Key words: LPPM, Knowledge Management System, Architecture Design, Blueprint

\begin{abstract}
ABSTRAK
LPPM adalah sebuah institusi di universitas, dapat dikatakan bahwa LPPM adalah sebuah tambang pengetahuan untuk kegiatan penelitian komunitas akademik. Fungsi LPPM terus berkembang tidak hanya sebagai tempat untuk menerbitkan karya penelitian, tetapi juga sebagai tempat untuk pengetahuan yang akan dieksplorasi. Sumber non-cetak seperti jurnal elektronik dan informasi yang dapat diakses melalui media web. Kebutuhan akan informasi ini memerlukan dukungan teknologi informasi yang dapat membantu LPPM menempatkan berbagai referensi pengetahuan bagi peneliti, dosen, mahasiswa, dan lainnya untuk mendapatkan pengetahuan berkualitas dengan mengakses jurnal penelitian yang dikelola oleh LPPM. Dengan keberadaan KMS, tentu dapat membantu dalam mengumpulkan, mengidentifikasi pengetahuan potensial, dan mengelola pengetahuan secara keseluruhan. serta dapat digunakan untuk mempercepat pengambilan keputusan pada masalah yang telah dialami sebelumnya. dengan menggunakan 10 langkah kerangka kerja tiwana amrit. hasil penelitian ini akan menghasilkan desain cetak biru arsitektur yang nantinya dapat digunakan sebagai referensi untuk implementasi pengembangan program atau pengembangan selanjutnya.
\end{abstract}

Kata Kunci: LPPM, Knowledge Management System, Perancangan Arsitektur, Blueprint

\section{PENDAHULUAN}

Knowledge management merupakan kegiatan dalam mengelola pengetahuan sebagai aset, dimana dalam berbagai strateginya ada penyaluran pengetahuan yang tepat kepada orang yang tepat dan dalam waktu yang cepat, hingga mereka bisa saling berinteraksi, berbagi pengetahuan dan mengaplikasikannya dalam pekerjaan sehari-hari demi peningkatan kinerja 
lembaga. LPPM adalah lembaga dalam sebuah Perguruan Tinggi, bisa dikatakan bahwa LPPM adalah tambang pengetahuan bagi kegiatan penelitian para civitas akademika. Fungsi LPPM terus berkembang tidak hanya sebagai tempat menerbitkan hasil karya penelitian, namun juga sebagai tempat yang dapat digali knowledge-nya. Sumber-sumber non cetak seperti jurnal elektronik dan informasi yang dapat diakses melalui media web. Kebutuhan terhadap informasi tersebut membutuhkan suatu dukungan teknologi informasi yang dapat membantu LPPM menempatkan berbagai referensi pengetahuan bagi peneliti, dosen, mahasiswa dan lainnya untuk mendapatkan pengetahuan yang berkualitas dengan cara mengakses jurnal penelitian yang di kelola oleh LPPM. Sebagai contoh sebelum sebuah jurnal dapat diakses oleh pengguna, peneliti atau dosen harus melakukan submit hasil penelitiannya ke jurnal tersebut. Aktivitas seperti ini sering menimbulkan masalah seperti hasil penelitian yang sudah pernah di publish ke jurnal lain, hasil penelitian yang di submit merupakan tugas akhir tetapi tidak mencantumkan nama dosen pembimbing dan lain sebagainya. tentunya masalah seperti diatas ditangani oleh staff ahli LPPM yang mengelola sebuah jurnal untuk menentukan keputusan. Ketika staff ahli yang mengelola sebuah jurnal dalam lembaga LPPM mengundurkan diri atau tidak masuk kerja pada saat terjadi permasalahan yang sama akan menimbulkan keraguan staff lain atau staff yang baru untuk menentukan keputusan kepada peneliti atau dosen yang melakukan submit hasil penelitiannya. Berdasarkan uraian diatas dapat disimpulkan bahwa Knowledge Management System diharapkan dapat mengatasi permasalahan transfer pengetahuan antar staff LPPM. Penelitian yang dilakukan oleh [1] dengan judul Methodology for the Implementation of Knowledge Management System 2.0, Hasil yang diperoleh menunjukkan efektivitas metodologi, karena membantu perusahaan ini untuk melaksanakan implementasi dengan cepat dan efektif, sehingga memungkinkan perusahaan untuk mendapatkan manfaat maksimal dari pengetahuan yang ada. Berdasarkan penelitian terdahulu tersebut, dapat disimpulkan bahwa manfaat dari Knowledge Management System dapat membantu untuk menentukan keputusan secara efektif dan efisien.

\section{TINJAUAN PUSTAKA}

\section{Knowledge Managemen}

Beberapa literatur mengungkapkan definisi manajemen pengetahuan. [2] mendefinisikan manajemen pengetahuan sebagai proses sistematik dan terorganisasi untuk memperoleh, mengatur, dan berkomunikasi baik pengetahuan tacit dan explicit sehingga karyawan lain bisa memanfaatkannya sehingga lebih efektif dan produktif dalam pekerjaan mereka. mendefinisikan manajemen pengetahuan adalah sistem yang memungkinkan perusahaan menyerap pengetahuan, pengalaman dan kreativitas para stafnya untuk perbaikan kinerja perusahaan. Dengan demikian $\mathrm{KM}$ adalah pengelolaan pengetahuan mulai dari mengumpulkan, menyimpan, mendistribusikan pengetahuan hingga di manfaatkan dan diperbaiki.

\section{a. Proses Dalam Management Pengetahuan}

Terdapat banyak definisi apa yang merupakan pengetahuan dan bagaimana pengetahuan diciptakan dan hubungannya dengan data dan informasi. Banyak organisasi membuat kesalahan dengan mengumpulkan data sebanyak banyaknya tanpa mendapatkan informasi dan pengetahuan dari data tersebut [3] organisasi yang akan menerapkan KM harus melakukan identifikasi pengetahuan penting yang dimiliki, menyimpan, menggunakan, menciptakan atau memperbaiki pengetahuan, dan seterusnya.

\section{b. Data, Informasi, dan Pengetahuan}

Menurut [4], data adalah simbol, informasi adalah data yang telah di proses untuk dapat menjawab pertanyaan "who", "what", "where", and "when", dan pengetahuan adalah data atau informasi yang dapat menjawab pertanyaan "how". Menurut [5] data adalah kumpulan fakta pengukuran dan statistik, informasi didefinisikan sebagai organisasi atau olahan data yang tepat waktu atau kesimpulan dari data yang diambil dalam jangka waktu penerapan yang akurat dengan mengacu pada data asli, sedangkan pengetahuan adalah informasi yang kontekstual, relevan dan ditindak lanjuti. Ini berarti bahwa pengetahuan memiliki pengalaman dan 
reflektif elemen yang kuat, yang membedakannya dari informasi dalam konteks tertentu. Dari definisi tersebut maka dapat dipastikan bahwa informasi pada tingkat lebih tinggi dari data dan pengetahuan adalah pada tingkat yang lebih tinggi dari informasi maupun data. Hubungan data, informasi dan pengetahuan dijelaskan pada gambar 1.

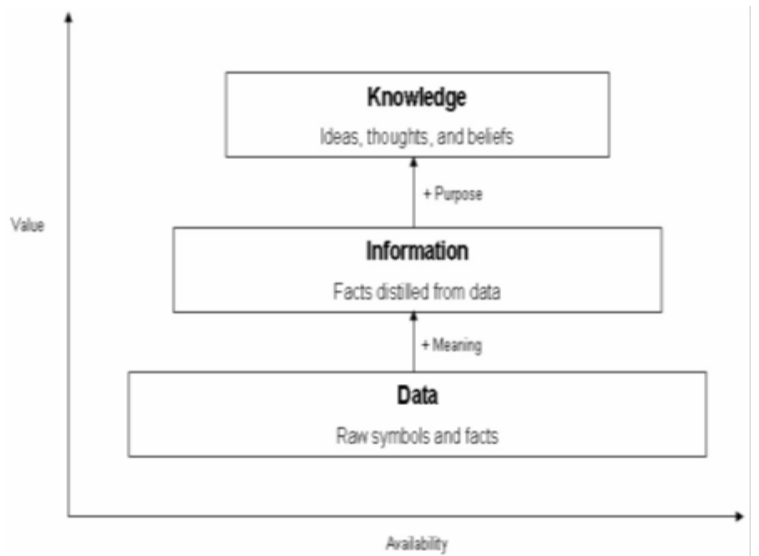

Gambar 1. Hubungan data, informasi dan pengetahuan

\section{c. Kerangka Kerja Amrit Tiwana}

Tiwana mengemukakan metodologi dalam membangun Knowledge Management System (KMS) digambarkan dalam tahap sebagai berikut [6].

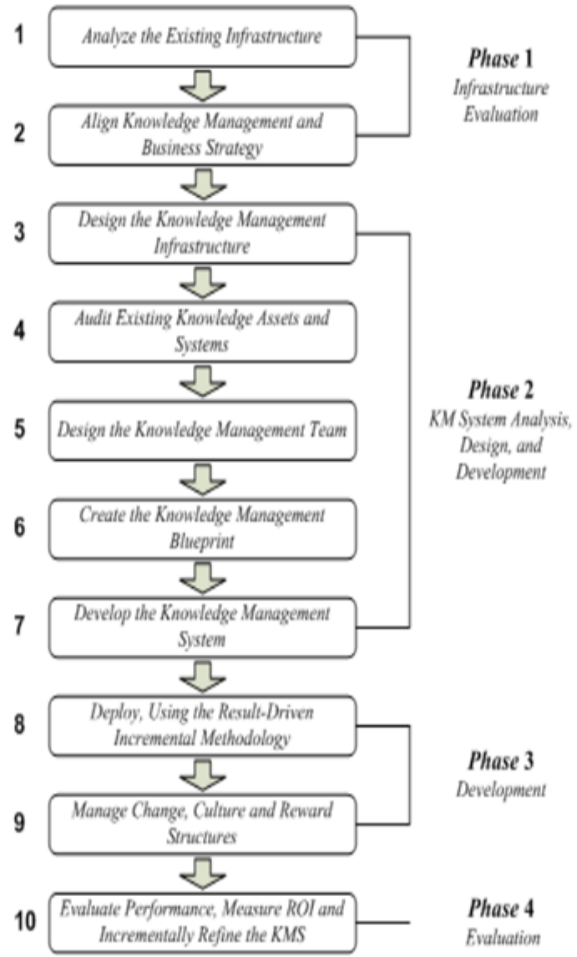

Gambar 2. Kerangka Kerja Amrit Tiwana

\section{METODE}

Dalam penelitian ini, proses pembuatan rencana model Knowledge Management System disusun melalui tahapan-tahapan seperti pada gambar 3 .

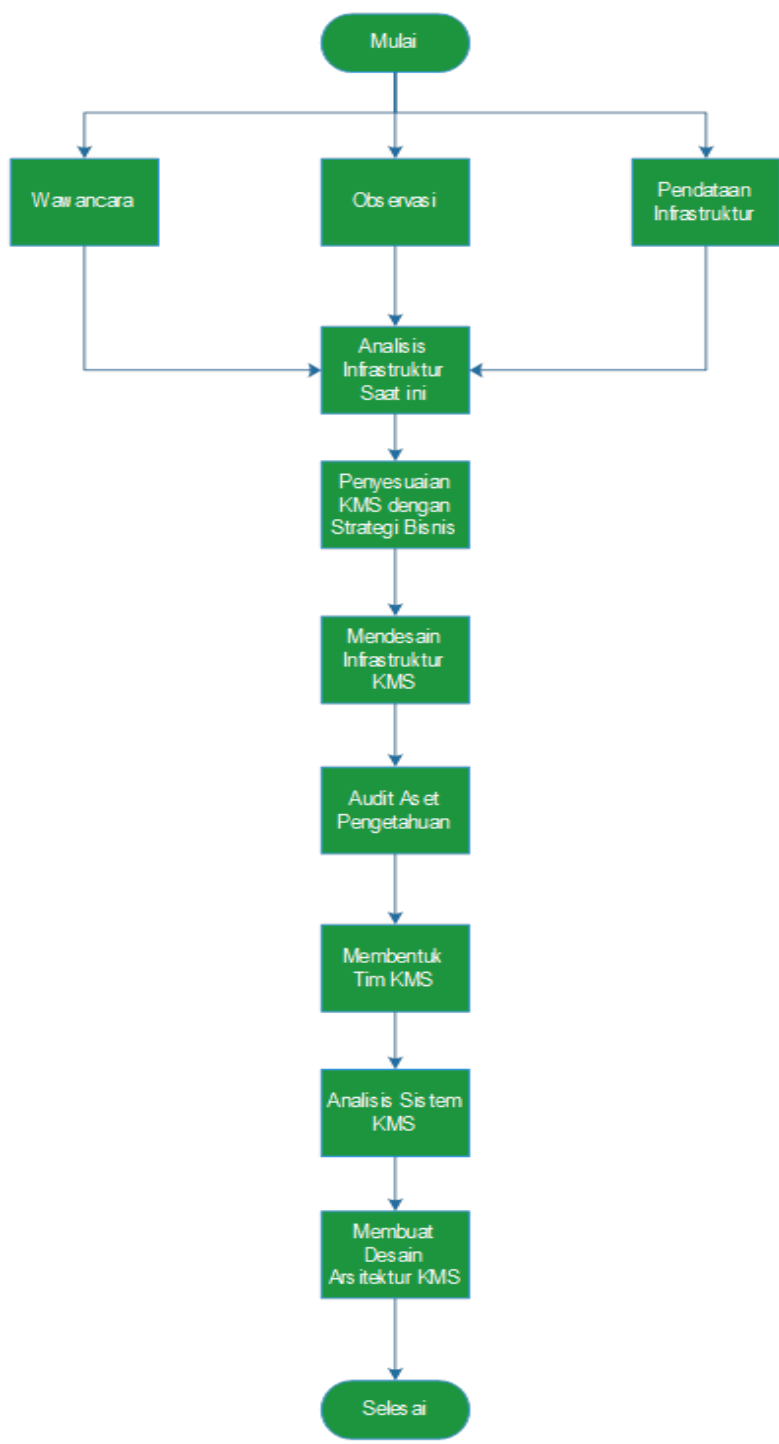

Gambar 3. Alur Penelitian

Tahapan pertama dari alur penelitian ini adalah dengan melakukan observasi pada LPPM, kemudian dilanjutkan dengan proses pengumpulan data dengan metode wawancara kepada petugas LPPM terkait masalah penelitian dan pengabdian masyaratkat. hasil observasi dan pengumpulan data selanjutnya dianalisis dan dirancang menggunakan metode the 10-step knowledge management roadmap. 


\section{HASIL DAN PEMBAHASAN}

\section{Analisis Kondisi Infrastruktur Saat Ini}

Berdasarkan hasil studi lapangan, didapatkan skema gambar teknologi jaringan pada STMIK STIKOM INDONESIA secara keseluruhan. Infrastruktur seperti yang digambarkan pada gambar 4.1 terbagi menjadi beberapa kelompok jaringan berdasarkan fungsi atau bagiannya. pada lembaga LPPM sudah memiliki infrastruktur yang memadai untuk menggunakan knowledge management system.

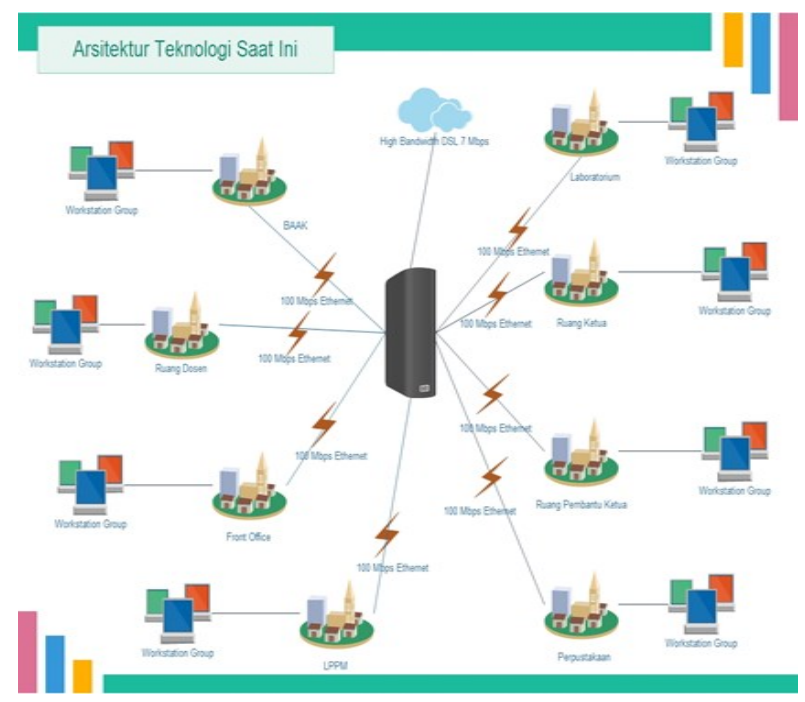

Gambar 4. Arsitektur Teknologi Saat Ini

\section{b. System Requirement}

Berdasarkan hasil strategi KMS dan tahapantahapan sebelumnya, maka dapat disusun daftar kebutuhan untuk KMS adalah seperti tabel 1.

Tabel 1. System Requirement

\begin{tabular}{|l|l|}
\hline No & \multicolumn{1}{|c|}{ Uraian } \\
\hline 1. & $\begin{array}{l}\text { Sistem hanya mengijinkan user yang terdaftar } \\
\text { untuk masuk }\end{array}$ \\
\hline 2. & $\begin{array}{l}\text { Sistem dapat menyimpan pengetahuan baik } \\
\text { uraian maupun file yang dikirim } \\
\text { oleh user }\end{array}$ \\
\hline 3. & $\begin{array}{l}\text { Sistem dapat menyimpan file program ap- } \\
\text { likasi, text, } \\
\text { gambar, dan video yang dikirim oleh user }\end{array}$ \\
\hline 4. & $\begin{array}{l}\text { Sistem menyediakan ruang diskusi untuk } \\
\text { membicarakan topik } \\
\text { tertentu pekerjaan }\end{array}$ \\
\hline 5. & $\begin{array}{l}\text { Sistem dapat menghubungkan antara forum } \\
\text { diskusi dengan file-file lampiran }\end{array}$ \\
\hline
\end{tabular}

\begin{tabular}{|l|l|}
\hline No & \multicolumn{1}{|c|}{ Uraian } \\
\hline 6. & $\begin{array}{l}\text { Sistem dapat digunakan untuk melakukan } \\
\text { pencarian pengetahuan }\end{array}$ \\
\hline 7. & $\begin{array}{l}\text { Sistem dapat digunakan untuk mendown- } \\
\text { load lampiran }\end{array}$ \\
\hline 8. & $\begin{array}{l}\text { Sistem dapat digunakan untuk melakukan } \\
\text { update pengetahuan oleh user }\end{array}$ \\
\hline 9. & $\begin{array}{l}\text { Antar muka sistem dalam bentuk web, } \\
\text { dapat diakses dari LAN maupun } \\
\text { internet, dari komputer desktop, notebook } \\
\text { maupun tablet atau smartphone }\end{array}$ \\
\hline 10. & $\begin{array}{l}\text { KMS mengakomodir tingkat kerahasiaan } \\
\text { dokumen }\end{array}$ \\
\hline
\end{tabular}

\section{c. Desain Infrastruktur KMS}

Berdasarkan infrastruktur teknologi yang telah ada saat ini, maka dibuat desain infrastruktur KMS seperti gambar 4.. Secara garis besar desain infrastruktur KMS yang baru terdiri dari infrastruktur umum (jaringan LAN), infrastruktur server KMS, dan infrastruktur administrator KMS.

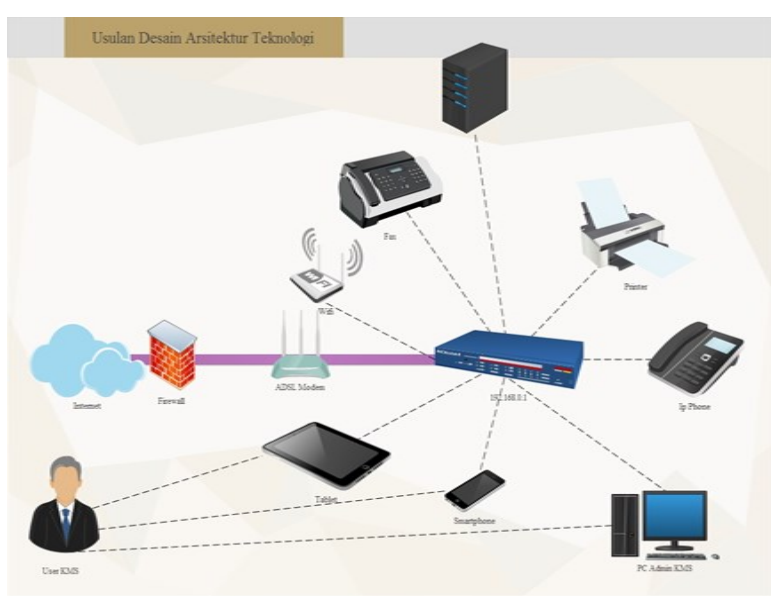

Gambar 5. Desain Infrastruktur KMS

d. Analisis Sistem KMS

Dari hasil-hasil langkah sebelumnya, di lakukan analisis sistem KMS secara keseluruhan untuk memenuhi requirement dan memaksimalkan sumber-sumber pengetahuan potensial. Meskipun berbeda-beda sumber yang telah dibahas sebelumnya akan tetapi secara garis besar terdapat kesamaan dalam mendapatkan pengetahuan, menyimpan, menyebarkan, dan melakukan perbaikan. Adapun konsep proses bisnis KMS yang diusulkan adalah seperti gambar 6 . 


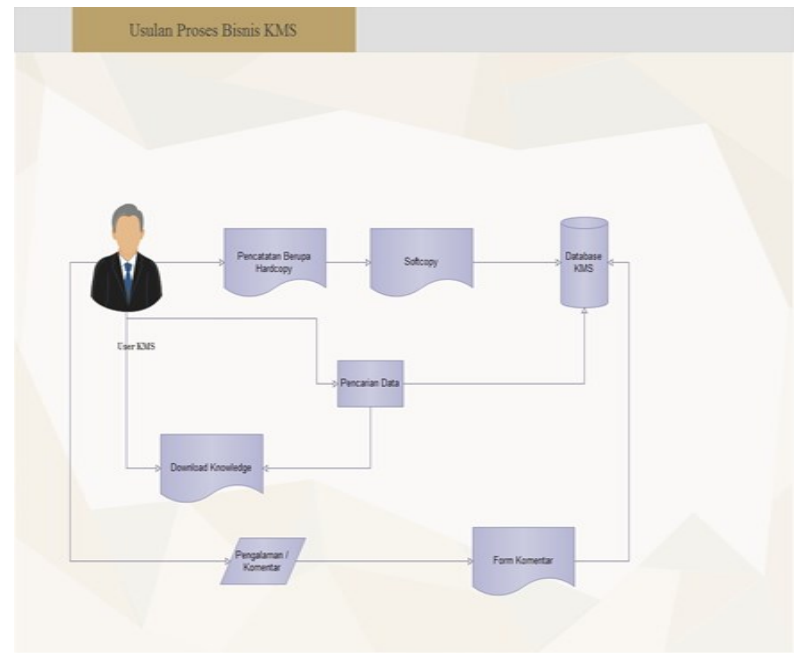

Gambar 6. Usulan Proses Bisnis KMS

Secara garis besar, pengetahuan berupa topik bahasan dalam forum, notulen rapat, dan lain lain disimpan langsung ke dalam database KMS (sama seperti meta document). Semua dokumen (pengetahuan) yang berbentuk hardcopy harus di rubah ke dalam softcopy terlebih dahulu agar dapat disimpan dalam KMS. sedangkan yang sudah berbentuk softcopy dapat disimpan langsung kedalam storage KMS. Sebelum di simpan, dokumen ini dibuatkan meta document dalam bentuk deskripsi. Deskripsi ini harus mewakili isi dokumen agar mudahdicari. Meta document ini disimpan dalam database KMS, sedangkan file disimpan dalam KMS storage. User dapat menambahkan pengalaman yang terkait dengan dokumen tersebut dalam bentuk komentar. Pencarian pengetahuan dengan cara memasukkan kata kunci. Pencarian ini dilakukan di database. Hasil pencarian adalah deskripsi dokumen beserta atributnya seperti link file, sedangkan file dokumen sendiri dapat di download langsung dari file server. Siklus pengetahuan akan berawal dari pengetahuan berupa topik bahasan, notulen rapat, email, dokumen atau project yang dimasukkan oleh user. User lain akan membaca, mempelajari dan memberikan masukan atau komentar. Komentar ini dapat berupa pengetahuan tambahan atau pengalaman. Pola interaksi ini akan memperbaiki pengetahuan yang ada sehingga semakin bermutu. Disisi lain, admin KMS memiliki akses secara penuh terhadap pengetahuan seluruh pengetahuan di KMS. topik yang usang atau dirasakan tidak bermanfaat dapat dihapus dari sistem.

\section{e. Use Case Diagram}

Use case diagram merupakan pemodelan untuk kelakuakn (behavior) sistem informasi yang akan dibuat. Use case digunakan untuk mengetahui fungsi apa saja yang ada di dalam sistem informasi dan siapa saja yang berhak menggunakan fungsifungsi tersebut.

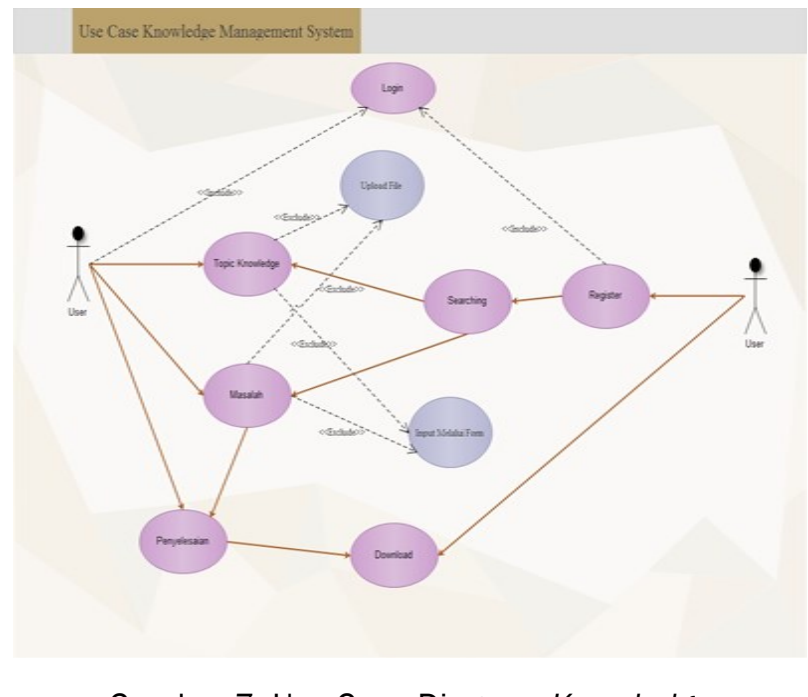

Gambar 7. Use Case Diagram Knowledge Management System

\section{f. Class Diagram}

Class diagram KMS Lembaga LPPM STMIK STIKOM INDONESIA ini menggambarkan bagian-bagian yang harus dibangun secara keseluruhan. Class diagram terdiri dari class-class yang memiliki fungsi sendirisendiri dan saling berkaitan untuk membentuk aplikasi secara utuh. 


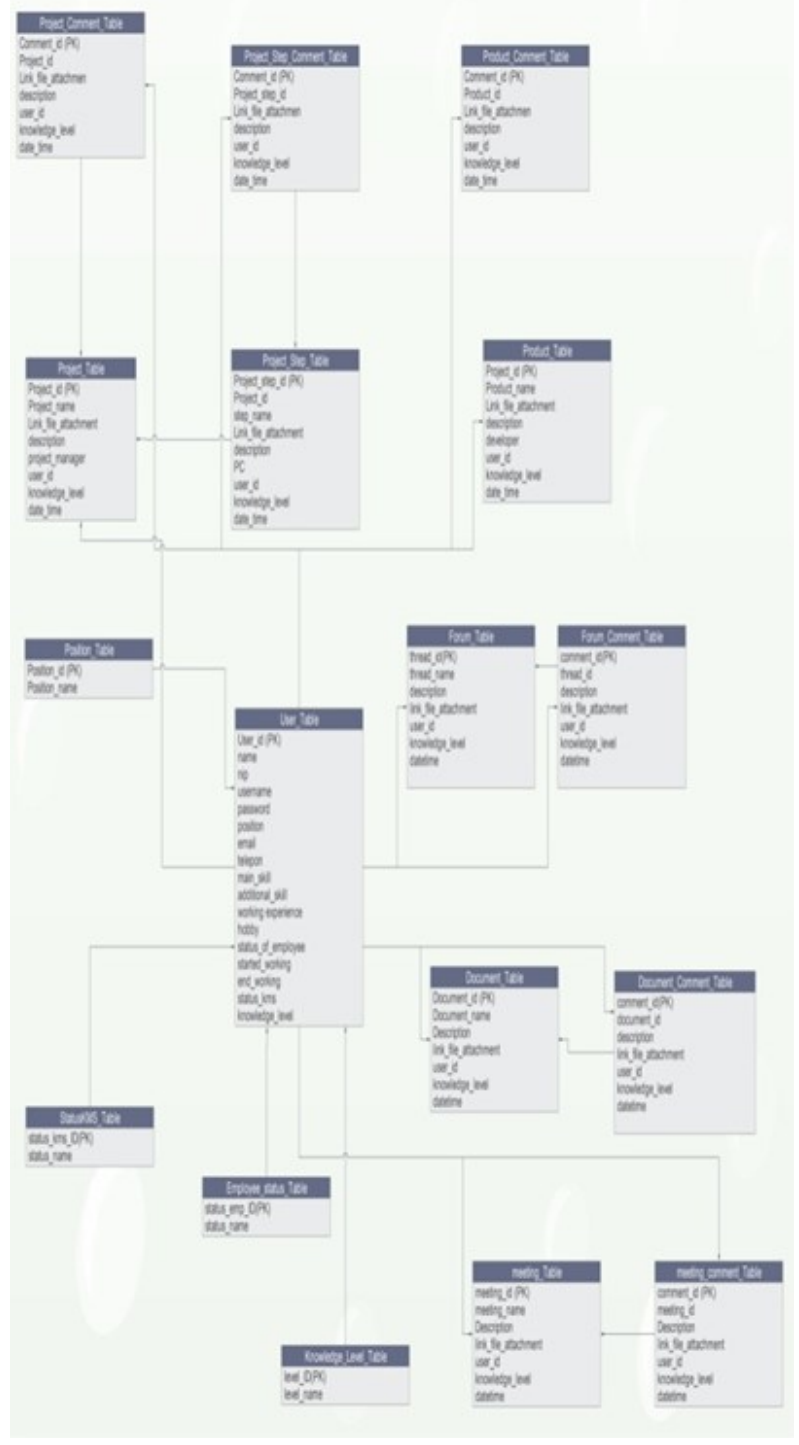

Gambar 8. Class Diagram Knowledge Management System

\section{G. Perbandingan Hasil}

Penelitian yang dilakukan oleh [7] yang berjudul KNOWLEDGE MANAGEMENT SYSTEM (KMS) DALAM MENINGKATKAN INOVASI LPPM PERGURUAN TINGGI," menghasilkan rancangan blueprint Knowledge Management System (KMS) sebagai berikut :

1. Kelompok knowledge worker yang dimaksudkan berupa kelompok peniliti dan dosen yang berpartisipasi untuk membangun basisdata pengetahuan yang berisi sekumpulan aturan untuk menentukan strategi, model dan arsitektur operasi. Kelompok ini dipimpin oleh seorang pemimpin kelompok yang disebut Chief Knowledge Officer (CKO).

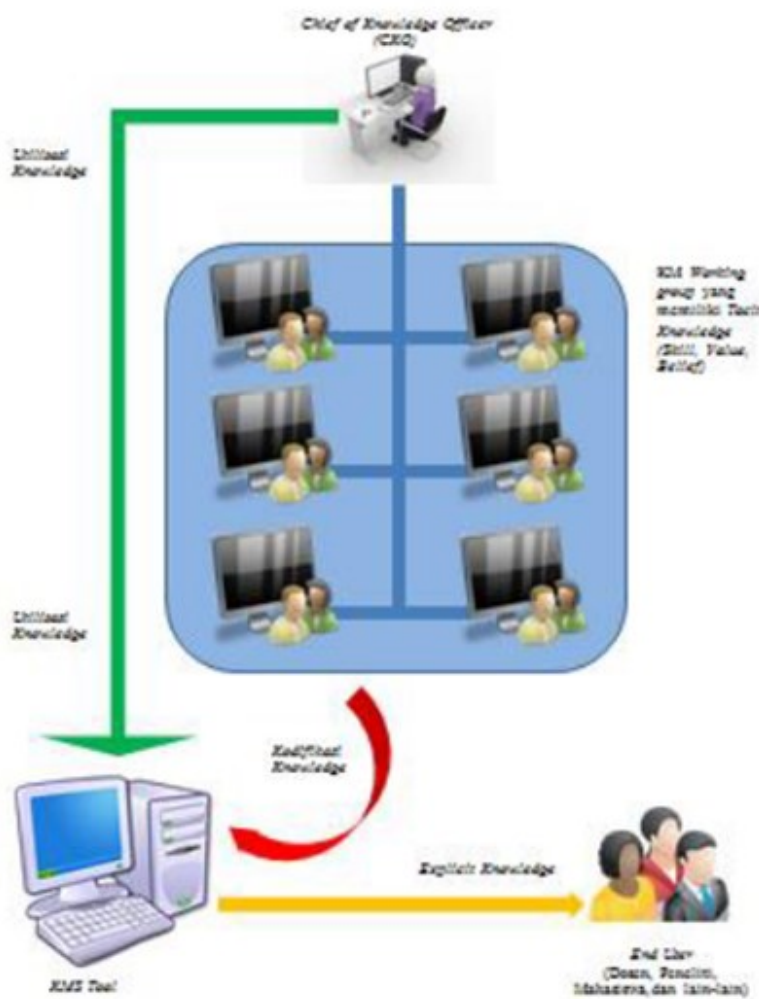

Gambar 9. Sistem CKO

2. Prototype KMS yang diusulkan untuk inovasi pada LPPM, dibuat sesuai dengan proses kebutuhan pada LPPM. Berikut digambarkan model prototype KMS yang diusulkan.

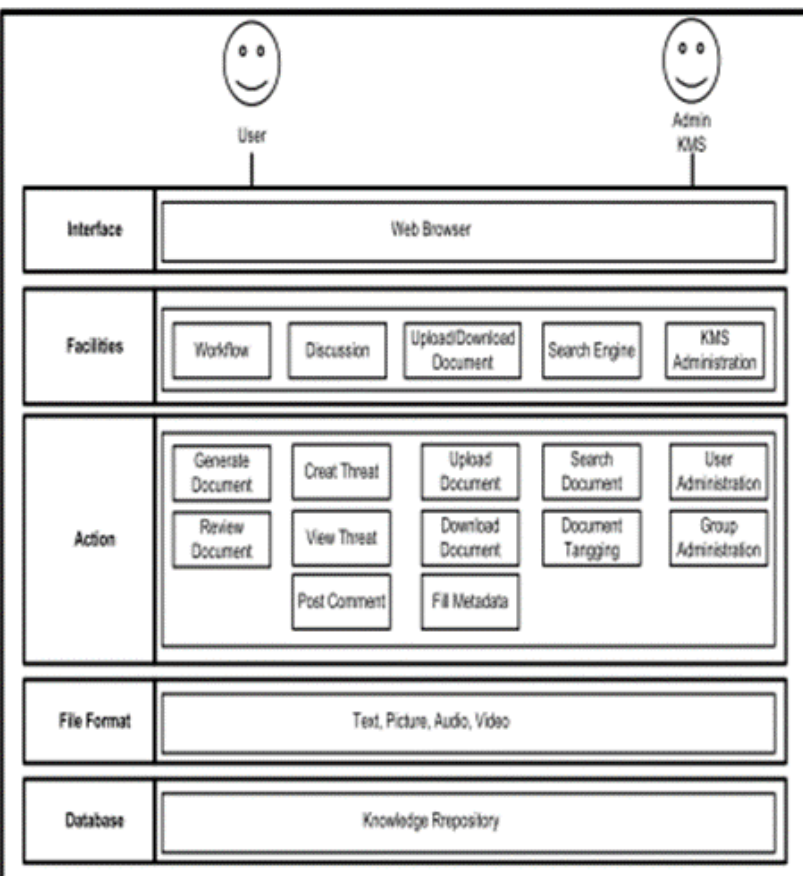

Gambar 10. Prototype KMS 
3. Dalam prototype tersebut terdapat proses perpindahan knowledge yang menggunakan sarana KMS yang ada pada LPPM. Adapun pemindahan knowledge tersebut meliputi :

- Proses Upload/Download Knowledge

- Proses Diskusi

- Proses Publikasi

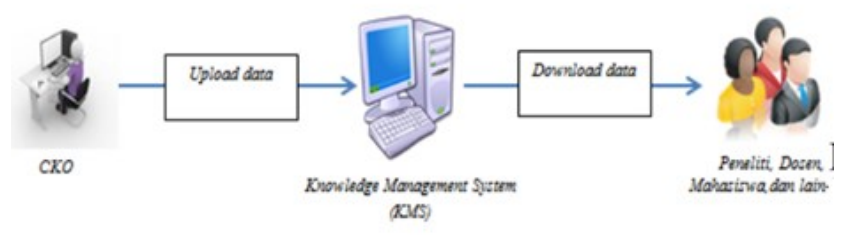

Gambar 11. Proses Upload/Download Knowledge

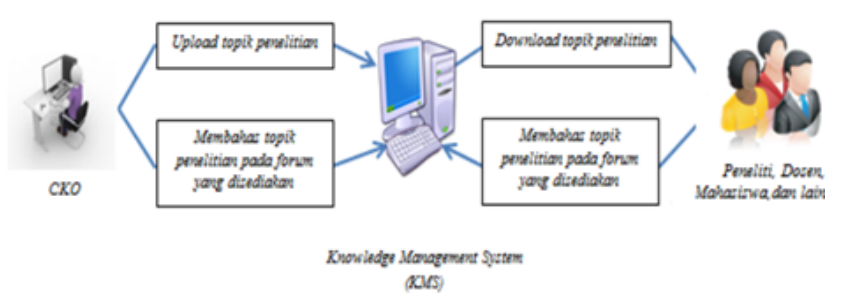

Gambar 12. Proses Diskusi

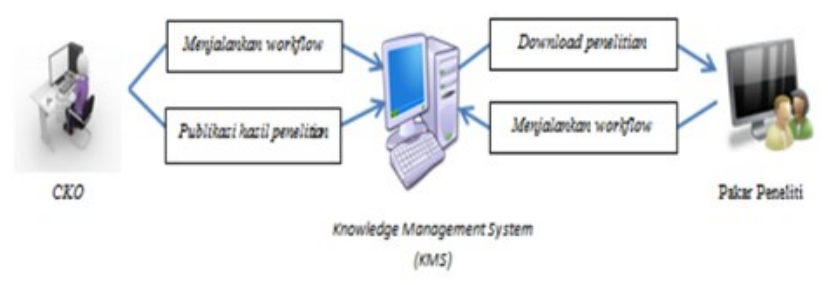

Gambar 13. Proses Publikasi

\section{KESIMPULAN}

Setelah melakukan penelitian dan melakukan analisis, maka penulis dapat menarik kesimpulan tentang perancangan arsitektur KMS pada Lembaga LPPM STMIK STIKOM INDONESIA sebagai berikut:

1. Kondisi $\mathrm{KM}$ saat ini baru mencakup sebagian kecil dari potensi pengetahuan yang dimiliki, banyak potensi pengetahuan yang dapat dikelola dan dimanfaatkan dengan lebih baik.

2. Dengan dirancangnya arsitektur knowledge management system ini akan dapat membantu staff baru pada lembaga LPPM STMIK STIKOM INDONESIA untuk menyelesaikan masalah yang sudah pernah terjadi sebelumnya.

\section{DAFTAR PUSTAKA}

[1] S. Orenga-Roglá and R. Chalmeta, "Methodology for the Implementation of Knowledge Management Systems 2.0," Bus. Inf. Syst. Eng., pp. 1-19, Dec. 2017.

[2] K. Iskandar, M. I. Jambak, R. Kosala, and H. Prabowo, "Current Issue on Knowledge Management System for future research: a Systematic Literature Review," Procedia Comput. Sci., vol. 116, pp. 68-80, 2017.

[3] R. Cerchione and E. Esposito, "Using knowledge management systems: A taxonomy of SME strategies," Int. J. Inf. Manage., vol. 37, no. 1, pp. 1551-1562, Feb. 2017.

[4] V. W. B. Martins, I. S. Rampasso, R. Anholon, O. L. G. Quelhas, and W. Leal Filho, "Knowledge management in the context of sustainability: Literature review and opportunities for future research," J. Clean. Prod., vol. 229, pp. 489-500, Aug. 2019. 
[5] L. G. Pee and A. Kankanhalli, "Interactions among factors influencing knowledge management in public-sector organizations: A resource-based view," Gov. Inf. Q., vol. 33, no. 1, pp. 188-199, Jan. 2016.

[6] Z. Jia, Y. Shi, Y. Jia, and D. Li, "A framework of knowledge management systems for tourism crisis management," in Procedia Engineering, 2012, vol. 29, pp. 138-143.

[7] E. R. Ningsih, "KNOWLEDGE MANAGEMENT SYSTEM (KMS) DALAM MENINGKATKAN INOVASI LPPM PERGURUAN TINGGI," EVOLUSI - J. Sains dan Manaj. AMIK BSI Purwokerto, vol. 1, no. 1, 2013. 